\title{
THE MOTIF OF REPENTANCE THROUGH THE PRISM OF NATURAL ELEMENTS IN “CRIME AND PUNISHMENT" BY F. DOSTOEVSKY
}

\author{
Olesia-Khrystyna Hlukhovska \\ Postgraduate Student, Ivan Franko National University of Lviv, Ukraine \\ e-mail: olesia.hlukhovska@lnu.edu.ua,orcid.org/0000-0002-4847-0285
}

\section{Summary}

The topic of Rodion Raskolnikov's spiritual transformation and repentance in "Crime and Punishment" has been a subject of constant debates among literary critics. This article aims to study the individual characteristics of imagery related to natural elements in F. Dostoyevsky's novel in the context of the motif of repentance. It also covers different interpretations of this motif in the world of literary studies and analyzes its implementation through the prism of fire, water, air, and earth images. It provides examples of how specific images related to natural elements can alter the perception of certain scenes and help form a deeper understanding of the character's physical, psychological and spiritual state. For example, the element of fire is represented by such images as the rays of the setting sun, a burning candle, and the morning light, all of which appear at key moments of the plot.

The results of the analysis highlight how specific elemental images can help uncover the protagonist's path from existential and physical suffering to remorse and, eventually, repentance.

Keywords: element images, Dostoyevsky, motif of repentance, realism, classical elements, fire.

\section{DOI https://doi.org/10.23856/3906}

\section{Introduction}

The motif of repentance in "Crime and Punishment" is a complex and controversial subject. This motif is presented in an ambiguous manner, which leads to constant discussions among researchers and literary critics. For instance, G. Hudyakova views the novel as a literary work that contains repentance, but as an event that hasn't occurred yet, as the protagonist still has a long way to travel on the path of his spiritual growth (G. Hudyakova, 1997: 23). L. Saraskina notes that in her opinion F. Dostoyevsky didn't manage to "take away the axe from the protagonist's hands and replace it with a cross" (Saraskina, 2017: 364-372). Meanwhile, T. Kasatkina considers Raskolnikov to be the representation of Jesus Christ and the resurrected Lazarus, as she states that Dostoyevsky depicts Jesus as a deep part of Raskolnikov and the Virgin Mary as a part of Sonya (Kasatkina, 2016: 74). Nature elements play an important role in uncovering the motif of repentance, which is why this aspect demands a detailed analysis in the context of the writer's artistic worldview.

The former consensus in the world of literary studies was that the usage of natural images is atypical for F. Dostoyevsky's discourse since the writer focuses his attention on the inner world of his characters. However, modern studies show that this belief isn't completely reflective of the truth, since images of natural elements play an important part in the writer's novels and can be considered as a key to understanding some of the ideas in Dostoyevsky's works. Such a point of view is maintained by G. Gachev, Yu. Lotman, A. Losev, F. Stepun, T. Kasatkina, I. Gazheva, D. Bogach, Yu. Karyakin, etc. The studies of the aforementioned 
authors describe the relevance of this topic in Dostoyevsky's works, but currently, there is no study that is dedicated to analyzing images of natural elements as tools for uncovering the motif of repentance in "Crime and Punishment". This fact proves the novelty of this study.

The aim of the article is to study the motif of repentance through the prism of natural elements in F. Dostoyevsky's "Crime and Punishment" and examine the individual characteristics of specific images-symbols that have nature element semantics.

This study is comprised of two parts. The first part of the analysis is dedicated to the motif of repentance and the description of different interpretations of this idea in F. Dostoyevsky's "Crime and Punishment." The second part of the article analyzes images related to the elements of fire, water, air, and earth, the peculiarity of their usage in the writer's works, and the connection of these images to the motif of repentance in the context of the novel.

\section{Existing interpretations of the motif of repentance in "Crime and Punishment"}

As noted in the introduction, L. Saraskina considers Raskolnikov's repentance to ring false. The researcher supports her belief by stating: "the author was an exceptionally honest artist that couldn't artificially impose the biblical feeling of deep remorse on a murderer that committed "righteous bloodshed", as that goes against both the truth and earthly laws" (Saraskina, 2017: 368). Next, the literary critic raises the question of whether a criminal's love towards a woman can resurrect them to the point of setting them on the path of sincere, deep repentance. "Neither Sergei Nechaev, who was in love in Herzen's daughter Tatu and was trying to win her favor, nor Andrej Zhelyabov, who tenderly loved his common-law wife Sof'ya Petrovskaya, nor the amorous and three-times married terror fanatic Boris Savinkov, nor anyone else that spilled "righteous blood" was resurrected by their love for women. They didn't cancel their terrorist attacks, they continued to carefully plan murders and regicide, sometimes along with their loved ones, they considered their crimes to be heroic feats and they remained unbroken even when dying on the scaffold" (Saraskina, 2017: 369).

G. Hudyakova takes a different stance on this subject and notes that the terms "remorse" and "repentance" are often treated as interchangeable. She mentions that in Dahl's Explanatory Dictionary the word "remorse" has a narrower meaning compared to "repentance": "... to repent, feel remorseful about one's action, to recognize that something wasn't supposed to be done or said". When a person is feeling remorseful, they only regret a specific action, without renouncing their former selves, unlike repentance, which is characterized by a "change of consciousness" (Hudyakova, 1997: 23).

"Remorse is self-reflective in nature - it doesn't seek to be unleashed outwards. A rational mind is hidden within itself and is self-sufficient. The subject of remorse confesses to himself or a specific confidant, but the pride in such a person is still rather strong and it doesn't allow them to bring "their sin" to the common court of the people" (Hudyakova, 1997: 23), this is how G. Hudyakova describes Raskolnikov's confession. The protagonist of this novel considers himself a victim of his own crime: "I killed myself, not that old creature" (Dostoyevsky, 1989: 354). Even the old woman he murdered laughs at the protagonist in his dream - "overcome with noiseless laughter, striving with all her powers to prevent him hearing it" (Dostoyevsky, 1989: 235). When Raskolnikov does confess, his confession contains shame for his spiritual disgrace and a humiliated but unbroken sense of pride, which are typical qualities of a person feeling remorseful about their mistake (Hudyakova, 1997: 24). G. Hudyakova states that the protagonist's confession to Sonya Marmeladova is something more than mere remorse, but still hasn't reached the level of repentance: "Sonya Marmeladova feels sorry for the murderer Raskolnikov, and that amazing 
display of sympathy and compassion cleanses the murderer's soul of pride for a moment: "Long unfamiliar feelings poured like a flood into his heart and melted it in an instant. He did not withstand them; two tears sprang into his eyes and hung on his lashes." (Dostoyevsky, 1989: 348). His shame and pride drowned in tears. This isn't remorse anymore, this is something deeper than remorse - a ray of heartfelt repentance. However, that repentance has yet to take root in Raskolnikov's soul, as he wasn't spiritually ready for it" (Hudyakova, 1997: 23).

T. Kasatkina also believes that remorse can be defined as one of the stages of repentance, while not predetermining that repentance will actually occur. Raskolnikov doesn't regret his crime almost throughout the entire novel. The stages that the protagonist goes through on his path of transformation: the public confession and a change of consciousness happen on the last pages of "Crime and Punishment", when Raskolnikov says: "can my feelings and thoughts not be the same as her (Sonya's) now?" (The exact passage in the novel goes as follows: "Could not her beliefs become my beliefs now? Her feelings, her aspirations, at least..." (Dostoyevsky, 1989: 464)) This means that after feeling that connection, he remodels his heart in accordance with Sonya, whom he treats as a prime example of what it means to be human. Thus, it's possible to conclude that the last lines of the novel are a hint at what awaits the protagonist in the future and that Raskolnikov's repentance will take place after all (Kasatkina, 2013). I. Dilman shares Kasatkina's opinion about Raskolnikov and states: "The transformation in which he will find wholeness, peace, and a new life comes to him in the very last two and half pages of the book" (Dilman, 2000: 197).

\section{Images of nature elements as literary devices that help convey the motif of repentance}

L. Karasev, in his article “About Dostoyevsky's symbols", talks about images that become symbols of a novel's world. When talking about the image of an axe in "Crime and Punishment," he mentions that this image became Dostoyevsky's symbol, or a supersign. The researcher then draws the comparison to other symbols that are associated with iconic literary works, such as the windmill in "Don Quixote" or the skull in "Hamlet". L. Karasev notes: “...the author's world doesn't rely solely on supersigns. It exists, predominantly, thanks to the combination of less noticeable, but still extremely important, symbolic details that together represent that special collection that we call "Dostoyevsky's symbols" or "Shakespeare's symbols". Such symbols are conveyed by traditional means and can be recognized by the regular appearance of the same elements in typologically similar situations" (Karasev, 1994). This statement is also relevant for identifying images related to fire, water, air, and earth elements in "Crime and Punishment", as they often manifest themselves in "typologically similar situations" (Karasev, 1994).

In regards to elemental imagery, T. Kasatkina states that in Dostoyevsky's "Crime and punishment" the images of natural elements can serve as a reflection of the characters' inner worlds. For instance, this is how she describes Raskolnikov's and Svidrigailov's perception of the city: "we see two completely different towns: through Raskolnikov's point of view, we perceive a sweltering, hot, dusty city, scorched by the sun, while through Svidrigailov, we see a wet, dark town that is full of water streams. This is how Dostoevsky conveys the idea that our environment is often determined by ourselves, formed by our mental state and consciousness" (Kasatkina, 2016: 75).

In scenes where natural elements represent the protagonist's inner self, they can act as a touchstone for analyzing the motif of repentance. For example, the images of fire accompany Raskolnikov even before the murder: "The little room was bright with the rays of the setting sun. The unexpected thought crossed his mind: The sun will be shining then, too, just as it does now!" (Dostoyevsky, 1989: 5). S. Durylin draws attention to the dualistic nature of the 
image's semantics: "the setting sun is a symbol of invulnerability, of the never-ending nature of existence: the setting sun, quiet and declining, also represents the sunrise: the sun as a unified whole" (Durylin, 1928).

The appearance of fire/light images not only precedes the tumultuous events of the novel, possessing negative connotations, but also manifests itself as the Divine Light. The ambivalent nature of such images can be traced in the following passages of the novel: "He stood up, looked round as if wondering how he came to be there, and walked away to the Tuchkov Bridge. He was pale, his eyes glittered, exhaustion filled every limb, but he had suddenly begun to breathe more easily. He felt that he had thrown off the terrible burden that had weighed him down for so long, and his heart was light and tranquil. "Lord!" he prayed, "show me the way, that I may renounce this accursed... fantasy of mine!” (Dostoyevsky, 1989: 51).

The rays of the setting sun are capable of awakening a feeling of deep remorse inside Raskolnikov: "He wandered aimlessly. The sun was going down. A particular sort of dejection had recently begun to show itself in him. There was nothing violent or poignant about it, but it carried with it a premonition of perpetuity, weary endless years of cold deadening depression, a presage of an eternity on "a hand's-breadth of ground". This feeling usually began to distress him even more towards evening" (Dostoyevsky, 1989: 360).

Throughout the entire novel, the morning sun never accompanies Raskolnikov. That only happens at the end, when Raskolnikov realizes his love for Sonya: "The day was again bright and warm. Early in the morning, at about six o 'clock, he went off to his work on the river-bank... From the other bank, far away, was faintly borne the sound of singing. There, in the immensity of the steppe, flooded with sunlight, the black tents of the nomads were barely visible dots. Freedom was there..." (Dostoyevsky, 1989: 463).

Such scenery can be interpreted as a symbol of Raskolnikov's future, his resurrection, and his transition from one "ideological world" to another.

It's important to mention that the element of fire can be manifested as either a flame or light. G. Bashlyar writes: "the perception of light as idealized fire is based on a phenomenal contradiction: sometimes, the fire is shining, but isn't burning; this occurs when its meaning is completely identified with purity. Light isn't just a symbol of purity, but also its active beginning." "In a place, where light has nothing to do, where it doesn't have things to divide or unite it passes freely. That what cannot be divided nor unified - is simple and pure" (Bashlyar, 1993).

I. Gazheva notes: "it's easy to notice that all descriptions of the slanting rays of the setting sun are interiorized in accordance to Dostoyevsky's overall tendency of interiorizing the materialistic world in his works. This means that the image of sunset rays is seldom a part of the author's speech, but is usually presented in the character's perception, signifying his reaction to God's presence. This characteristic correlates with the motif of Christ's silence, which was described by G. Pomeranz: "Jesus Christ remains silent. He is simply present and his presence affects both the characters who listen to him and those that don't - everybody". Similarly, the sunset rays are also "simply present", they penetrate the window and, depending on the internal condition of the protagonist, either burn or illuminate him (Gazheva, 2018).

In the context of what was stated above, it's important to analyze the image of a candle. According to G. Bashlyar, a candle's flame is a sign of loneliness. The researcher also notes: "a candle is the luminary of a clean slate". When examining the text of this novel, it becomes evident that candlelight is present in one of the narrative's key moments. It can be found in the scene where Sonya reads the Gospel in Raskolnikov's presence: "The candle-end had long since burned low in the twisted candlestick, dimly lighting the poverty-stricken room and the murderer and the harlot who had come together so strangely to read the eternal book" 
(Dostoyevsky, 1989: 278). The symbolic connotation of "loneliness" that is tied to the candle image is relevant for both characters: Sonya, who is alone with her suffering, and Raskolnikov, who has to be punished for murder on his own. At the same time, the candle, just like the image of slanting rays of the setting sun - is an ambivalent image, as it also acts as a symbol of transformation and a new life.

It's important to mention that candlelight never appears in Raskolnikov's room. His home is never illuminated at night, which is constantly highlighted by the author, who describes the room as cramped, suffocating, resembling a coffin. This semblance also affects the protagonist's mental state: "But do you know, Sonya, that low ceilings and cramped rooms crush the mind and the spirit? Oh, how I hated that hole. But all the same I would not leave it... I had no light at night, and I lay in the dark, because I wouldn't earn the money for candles... And all the time I had such dreams, all sorts of strange dreams;" (Dostoyevsky, 1989: 352). The dichotomy of Light and Darkness, just like Good and Evil, can be traced in the following dialogue between Raskolnikov and Sonya: "Hush, Sonya, I am not laughing. I know myself that it was the devil dragging me along. Hush, Sonya, hush!" he repeated with gloomy insistence. "I know all that. I thought it all out and whispered it over to myself, while I lay there in the dark..." (Dostoyevsky, 1989: 353).

Water images also play an important part in the novel's narrative. The space of "Crime and Punishment" is largely built around this element. For instance, one of the places that Raskolnikov visits is a bridge that becomes the location of poignant events both before and after his crime. The bridge represents a symbolic border between the Sky and Earth, Good and Evil, as well as a physical embodiment of the moral line that is crossed by the protagonist.

As mentioned earlier, when Raskolnikov sees the rays of the setting sun, he refuses to believe that he planned to commit murder. Those thoughts come to him when he is standing on the bridge, admiring the sunset. That moment is followed by the fateful events of the novel. Once the crime was committed, Raskolnikov returns to the bridge to drop the evidence into the water: "Raskolnikov went straight to the Voznesensky Bridge, stopped in the middle of it, leaned both elbows on the parapet, and gazed along the canal... Leaning over the water he looked mechanically at the last pink reflections of the sunset, at the row of buildings growing dark in the thickening dusk, at one distant window, high up in some roof along the left bank, that shone for an instant with flame as the last ray of the dying sun caught it, at the darkening water of the canal" (Dostoyevsky, 1989: 144).

In that passage, the author highlights the fact that the sunset has already passed, Raskolnikov is looking at it "mechanically", and it's also important to note that the protagonist doesn't see the sunset itself, as before, only its reflection. "the last pink reflections of the sunset" - a sign that Raskolnikov's soul is now covered by the darkness of sin.

Water images are frequently found in Raskolnikov's dreams. In one of them, the author writes about an oasis, at the stream of which Raskolnikov drinks water: "He lost himself in a maze of waking dreams, and very strange ones they were; in the one that recurred most often he was in Africa, in Egypt, at some oasis. A caravan was resting, the camels lying peacefully and the men eating their evening meal; all around, the palms stood in a great circle. He was drinking the water from a stream which flowed babbling beside him, clear and cool, running marvelously bright and blue over the coloured stones and the clean sand with its gleams of gold..." (Dostoyevsky, 1989: 58).

This scene creates a striking contrast between reality and the dream world, and it can also be simultaneously interpreted as a reference to the present, as a direct warning on the eve of the planned murder, and to the protagonist's future, his possible repentance, and the cleansing of his 
soul. A. Borodina notes that the most important detail in Raskolnikov's dream is the presence of a vitality source that Rodion eagerly drinks from. The stream's waters have dual meaning, as they can be of either "subterranean" or "heavenly" origins, meaning they could bring either chaos or renewal (Borodina, 2005).

Another poignant moment that highlights how water images serve to forward the motif of repentance can be found in the scene where everyone is eating, while Raskolnikov is only drinking water. In the context of that passage, it's important to remember the following lines from A. Pushkin's iconic poem the "Prophet":

"When, pained with spiritual thirst,

I trudged across a gloomy desert,

I came upon a six-winged seraph

Who stood before me on my path..." (Pushkin, 1826: 149).

This detail can be interpreted as the author's way of showing that Raskolnikov is on his way to repenting for the murder he committed and that he is already suffering from "spiritual thirst" without realizing it.

Dostoyevsky also uses images of water as a character-building tool. For instance, after meeting Sonya Marmeladova, Raskolnikov compares her to a well that other people spit in: "Poor Sonya! What a little gold-mine ("well" in the original text) they've managed to get hold of there! - and profit from! Oh yes, they draw their profits from it! And they've got used to it. They wept at first, but now they are used to it. Men are scoundrels; they can get used to anything!" (Dostoyevsky, 1989: 22). According to archaic beliefs, a well is the lair of evil spirits. This motif can be found in Russian folklore fairy-tails as well as literary ones like "About Tsar Berindei" by Zhukovsky.

According to Christian tradition, a well is a source of new life and salvation. A prime example is Jesus' meeting with a Samaritan woman when Christ asks to drink water from the well and the woman finds out she is speaking to the Savior himself. It's not a coincidence that Raskolnikov uses that word to describe Sonya. On the one hand, she becomes his salvation and the foundation for his belief in a new life, but on the other hand, we can see the similarities between her and the Samaritan woman, as both are defiled by society while having an unbending faith in God.

Earth element images also play an important role in conveying Raskolnikov's path towards repentance. For instance, in the passage where he thinks about Sonya's plead for him to repent in front of the ground that he desecrated and kiss it, he: "He had suddenly remembered Sonya's words: "Go to the cross-roads; bow down before the people, and kiss the ground, because you are guilty before them, and say aloud to all the world, "I am a murderer!" "A shudder shook his whole body at the remembrance. He was so crushed by the weight of all the unescapable misery and anxiety of all this time, and especially of these last hours, that he almost flung himself on the possibility of this new, complete, integral sensation. It had come down on him like a clap of thunder; a single spark was kindled in his spirit and suddenly, like a fire, enveloped his whole being. Everything in him softened on the instant and the tears gushed out. He fell to the ground where he stood... He knelt in the middle of the square, bowed to the ground, and kissed its filth with pleasure and joy. He raised himself and then bowed down a second time..." (Dostoyevsky, 1989: 444-445).

The earth element occupies a special place in Dostoyevsky's works as a whole. It's represented in a syncretic manner and includes both pagan and Christian traditions: "...for F. Dostoyevsky, the earth isn't just a substance that gives life to things; the earth is, first of all, the original source of spirituality, since the idea of resurrecting a spiritually dead man is tied to the mythologeme of mother-earth" (Skuridina, 2016). 
In his works, F. Dostoyevsky often relies on mythological traditions that are embodied in the image of Mother-Earth. According to Yu. Lotman, "the image of Earth stands against two destructive elements as a fertile, prosperous force. Opposing water as "solid", Earth gains characteristics that the cultural tradition usually associates with the Sky, properties of perfect existence" (Lotman, 1983: 818).

Elemental imagery is also involved in constructing the image symbol of "an eternity on a hand's-breadth of ground" that Raskolnikov talks about after the murder: "where was it that I read of how a condemned man, just before he died, said, or thought, that if he had to live on some high crag, on a ledge so small that there was no more than room for his two feet, with all about him the abyss, the ocean, eternal night, eternal solitude, eternal storm, and there he must remain, on a hand's-breadth of ground, all his life, a thousand years, through all eternity - it would be better to live so, than die within the hour?" (Dostoyevsky, 1989: 135).

This image becomes both a symbol that is important for a deeper understanding of the novel and a recurring detail. The usage of this image can also be tracked later: "A particular sort of dejection had recently begun to show itself in him... a presage of an eternity on "a hand'sbreadth of ground" (Dostoyevsky, 1989: 360).

The image of "an eternity on a hand's-breadth of ground" is a multi-layered one. The "hand'sbreadth of ground" isn't just Raskolnikov's cramped room, Sonya's poor dwelling, or the hardships that the characters had to endure. This image is also connected to the quest of finding a way out of the difficult dead ends that Dostoyevsky's characters find themselves in. Raskolnikov was in such a spiritual dead end when he was about to leave the old pawnbroker-lady, he "changed his mind, remembering that he had nowhere else to turn..." (Dostoyevsky, 1989: 5). That "nowhere" isn't just connected to his domestic or financial situation, but also conveys a sense of hopelessness, the desperate condition of Raskolnikov, who really did have "nowhere else to turn". The protagonist is suffocating in his uncomfortable quarters and is suffocating in the pawnbroker-lady's flat, and all of that suffering is also included in the author's image of "an eternity on a hand's-breadth of ground".

Analyzing and interpreting air images is another key part of showing the relation between the motif or repentance and elemental imagery. After Raskolnikov commits murder, he suffers from a constant lack of air. The space around the protagonists feels sultry, which leads to him losing consciousness and an aggravation of his suffering: "It's only about some silly formality, or perhaps some trifling indiscretion, and I might have given myself away completely! Hm... it's a pity there's no air here... he went on, it's stuffy... My head seems to be spinning worse than ever, and my thoughts with it..." (Dostoyevsky, 1989: 81).

Three days after his crime, Raskolnikov goes out in the street and starts feeling sultry again: "It was about eight o'clock and the sun was going down. The heat was still as oppressive as before, but he greedily breathed the dusty, foul-smelling, contaminated air of the town. His head began to feel ever so slightly dizzy; a wild kind of energy flared up in his sunken eyes and pallid wasted face. He did not know, or stop to think, where he was going; he knew only one thing: that he must finish with all this today, once and for all, and at once; that otherwise he would not go back home, because he would not live like this!" (Dostoyevsky, 1989: 132).

The protagonist's home also serves to create the impression of an "airless" space. It's described by other characters as a "ship cabin" or a "coffin". For instance, Razumikhin says: "This place is no better than a ship's cabin, he exclaimed as he came in; I always bump my head. And they call it a lodging!" (Dostoyevsky, 1989: 100).

Pulcheria Alexandrovna compares the flat to a coffin: "What a dreadful room you have, Rodya, just like a coffin, said Pulkheria Alexandrovna, breaking the oppressive silence. I'm sure it is responsible for at least half your depression" (Dostoyevsky, 1989: 196). 
The "air" lexeme is also used by F. Dostoyevsky in a metaphorical sense. As mentioned above, Raskolnikov constantly struggles to breathe and that theme is further continued by characters like Razumikhin, Porfiry Petrovich, and Svidrigailov. It's crucial to note that all of them repeat the same phrase: "Every man needs air, air, air!", as this phrase also becomes important for the novel's plot as through it Raskolnikov understands that his conversation with Sonya Marmeladova was eavesdropped by Svidrigailov, same as the dialogue between Raskolnikov and Razumihkin was eavesdropped by Porfiry Petrovich.

Let's take a closer look at all three scenes where this phrase is mentioned. The first scene occurs after the death of Katerina Ivanovna, when Svidrigailov takes Raskolnikov to the side and after a brief conversation admits that he eavesdropped on Raskolnikov's conversation with Sonya. Later, continuing the interrupted conversation, he asks: "Why, what is it, Rodion Romanovich? You aren't well! Really! You look and listen, but you don't seem to understand. Pull yourself together. Look, let us have a talk; but, unfortunately, I have so much business to attend to, both of my own and of other people's... Ah, Rodion Romanovich,' he added suddenly, every man needs air, air, air!... More than anything!" (Dostoyevsky, 1989: 371).

Raskolnikov is puzzled by these words and when Razumikhin visits him a few days later, the protagonist says: "Yesterday somebody said to me that a man needs air, air, air! I must go to him at once and find out what he means by that" (Dostoyevsky, 1989: 375).

The last time, these words are pronounced by Porfiry Petrovich: "plunge straight into life, without deliberation; don't be uneasy - it will carry you direct to the shore and set you on your feet... As you took such a terrible step, now you must take courage. That is justice. Do what justice demands. I know you do not believe me, but it is the sacred truth that life will sustain you. Afterwards you will regain your self- esteem. Now you need only air, air, air!” (Dostoyevsky, 1989: 388-389).

Since elemental imagery is interiorized and written into the character's inner worlds, Raskolnikov's constant quest for "air" can be interpreted as a subliminal representation of his hope to start life anew despite the heavy crime that is weighing down his soul. It speaks volumes that the phrase "air, air, air" only appears after Raskolnikov's confession to Sonya, and that the constantly sultry, suffocating space that was surrounding the protagonist throughout the novel is replaced with the vast open steppe in the epilogue. The epilogue is also the section where images of the sunlight and the morning light (dawn) are introduced: "the immensity of the steppe, flooded with sunlight, the black tents of the nomads were barely visible dots. Freedom was there, there other people lived, so utterly unlike those on this side of the river that it seemed as though with them time had stood still, and the age of Abraham and his flocks was still the present. Raskolnikov sat on and his unwavering gaze remained fixed on the farther bank; his mind had wandered into daydreams; he thought of nothing, but an anguished longing disturbed and tormented him. Suddenly Sonya appeared at his side... They tried to speak, but they could not. Tears stood in their eyes. They were both pale and thin, but in their white sick faces there glowed the dawn of a new future, a perfect resurrection into a new life. Love had raised them from the dead, and the heart of each held endless springs of life for the heart of the other" (Dostoyevsky, 1989: 463).

The above passage is another sign of the protagonist's future repentance and the possible salvation of his soul.

\section{Conclusions}

Images related to elements of fire, water, air, and earth play an important part in F. Dostoyevsky's works, despite the commonly-accepted belief that usage of elemental imagery is uncharacteristic for the author's discourse. 
This study discloses the importance of the motif of repentance in "Crime and Punishment" and analyses the interrelationship between this motif and images of natural elements. For instance, "the rays of the setting sun" are capable of evoking a feeling of deep remorse in Raskolnikov, while the image of a candle, on the one hand, unites Sonya and Raskolnikov, and on the other hand - becomes a separation point of the characters' locus, as the candlelight only burns in Sonya's house, while Raskolnikov's lodging is described as dark and constantly void of light.

The water element is used to build the location of "Crime and Punishment". For example, one of the places that Raskolnikov visits is a bridge that appears both before and after the murder. In this case, the bridge acts as a boundary between Sky and Earth, Good and Evil, and as a material embodiment of the moral line crossed by the protagonist.

The earth element occupies a special place in F. Dostoyevsky's works and is represented in a syncretic manner while being oriented at both pagan and Christian traditions. Since "earth" is a static element, it is contrasted with the dynamic elements of fire, water, and air, as the author grants it a sacral meaning. Earth gains characteristics that the cultural tradition usually associates with the Sky.

The analysis and interpretation of air element imagery are also important in uncovering the motif of repentance. Once he becomes a murderer, Raskolnikov suffers from a constant lack of air. In a metaphorical sense, the protagonist's suffocation and the sultriness that surrounds him represent the world of sin that he lives in. After Raskolnikov confesses to Sonya and starts feeling remorseful, other characters like Porfiry Petrovich push him to find "air, air, air," which he manages to do in the epilogue. The "air" that Raskolnikov finds on the wide-open steppe along with the image of "dawn" can also serve as proof of his future transformation and repentance.

\section{References}

Bashlyar, G. (1993). Psihoanaliz ognya [Psychoanalysis offire]. (N.V. Kislov, Trans). Moscow: Progress. [in Russian].

Bashlyar, G. (1998). Voda i grezy [Water and dreams]. (B.M. Skuratov, Trans). Moscow: Izdatelstvo gumanitarnoj literatury. [in Russian].

Blagoj, B.B., Bondi S.M., Vinogradov, V.V., Oksman, Yu.G. (Ed.). (1959). A.S. Pushkin. Sobranie sochinenij v 10 tomah. [A.S. Pushkin. Complete works in 10 volumes]. (Vols. 2), (pp. 149-150). Moscow: Gosudarstvennoe izdatelstvo hudozhestvennoj literatury. [in Russian].

Bogach, D.A. (2017). Priroda kak cennost v nasledii F.M. Dostoevskogo [The value of nature in the heritage of F.M. Dostoevsky]. Ekaterinburg: Kabinetnyj uchenyj. [in Russian].

Borodina, A.V. (2005). O vospityvayushem potenciale tvorchestva F.M. Dostoevskogo [About the educational potential of F.M. Dostoevsky's works]. Obrazovanie - Education, 1, 47-63. [in Russian]. Dilman, I. (2000). Raskolnikov's Rebirth: Psychology and the Understanding of Good and Evil. Peru: Open Court Publishing Company. [in English].

Durylin, S.N. (1928). Ob odnom simvole u Dostoevskogo [About one of Dostoyevsky's symbols]. Moscow: GAHN. [in Russian].

Gazheva, I.D. (2018). Svet vechernij v tvorchestve F.M. Dostoevskogo [Evening light in the works of F.M. Dostoevsky]. Sultanivski chitannya: zbirnyk statej - Sultanivski chitannya: book of articles, 7, 225-242. [in Russian].

Gibian, G. (Ed.) (1989). Feodor Dostoyevsky: Crime and Punishment. Third Edition. The Coulson Translation. Background and Sources. Essays in Criticism. New York: W. W. Norton \& Company, 1-465. [in English]. 
Hudyakova, G.P. (1997). Urovni ispovedalnosti: raskayanie i pokayanie [Levels of confession: remorse and repentance]. Proceedings of the International Scientific Conference: Metafizika ispovedi. Prostranstvo i vremya ispovedalnogo slova - Confession metaphysics. The space and time of a confessional word. (p. 23).

St.Petersburg: Izd-vo Instituta Cheloveka RAN (SPb Otdelenie). [in Russian].

Karasev, L.V. (1994). O simvolah Dostoevskogo [About Dostoyevsky's Symbols]. Voprosy Filosofii-Questions of Philosophy, 10, 90-111. [in Russian].

Karyakin, Yu.F. (1976). Samoobman Raskolnikova [Raskolnikov's self-deception]. Moscow: Hudozhestvennaya literature. [in Russian].

Kasatkina, T.A. (2015). Svyashennoe v povsednevnom: dvusostavnyj obraz v proizvedeniyah F.M. Dostoevskogo [The sacred in the mundane: dualistic images in the works of F.M. Dostoevsky]. Moscow: IMLI RAN. [in Russian].

Kasatkina, T.A. (2016). 9 voprosov o Prestuplenii i nakazanii. [9 questions about 'Crime and Punishment']. Foma - Foma, 12, 74-80. [in Russian].

Kasatkina, T.A. (2013). Pokayanie u F.M. Dostoevskogo [Repentance in the works of F.M. Dostoevsky]. Videokanal N. Podosokorskogo - N.Podosokorsky's video channel. Retrieved from https://www.youtube.com/watch?v= AmTa17 YmTsg [in Russian].

Lotman, Yu. (1995). Obrazy prirodnyh stihij v russkoj literature (Pushkin - Dostoevskij - Blok) [Images of natural elements in Russian literature (Pushkin - Dostoevsky - Blok). Fundamentalnaya elektronnaya biblioteka: russkaya literatura i folklor. - Fundamental Electronic Library: Russian Literature and Folklore Retrieved from http://febweb.ru/feb/classics/critics/lotman/lot/ lot-814-.html [in Russian].

Saraskina L.I. (2017). Fantom raskayaniya Rodiona Raskolnikova v sovremennyh adaptaciyah romana F.M. Dostoevskogo 'Prestuplenie i nakazanie' [The phantom of Rodion Raskolnikov's repentance in modern adaptations of F.M. Dostoevsky's novel 'Crime and Punishment']. Mundo eslavo: revista de cultura y estudios eslavos. - Slavic World: Magazine of Slavic Studies and Culture, 16, 364-372. [in Russian].

Sedakova, O.A. (2019). Pokayanie i tvorchestvo [Repentance and creativity]. Videokanal Püha Johannese Kool - Video channel Püha Johannese Kool: Retrieved from https://www.youtube. com/watch? $v=y b c X l I J f 5 Z 4$ [in Russian].

Skuridina, S.A. (2016). Mat-Syra-Zemlya kak mifopoeticheskaya konstanta tvorchestva F.M. Dostoevskogo: onomasticheskij aspect [Mother-Damp-Earth as a mythopoetic constant of F.M. Dostoevsky's works: the onomastic aspect]. Vestnik Slavyanskih Kultur - Bulletin of Slavic Cultures,4, 143-150. [in Russian].

Zaharov, V.N. (Ed.). (1989). F.M. Dostoevskij. Sobranie sochinenij v 15 tomah. [F.M. Dostoevsky. Complete works in 15 volumes]. (Vol. 5). Leningrad: Nauka. [in Russian]. 